\title{
Impact of inter-metallic compound thickness on thermo-mechanical reliability of solder joints in solar cell assembly
}

\author{
Musa T. Zarmai ${ }^{*}$, Chike F. Oduoza ${ }^{2}$ \\ ${ }^{1}$ Department of Mechanical Engineering, \\ University of Abuja, Nigeria \\ ${ }^{2}$ School of Engineering, \\ University of Wolverhampton, WV1 1LY, UK \\ "Email address: musa.zarmai@ uniabuja.edu.ng ; Phone number: +234(0)8051364611
}

\section{Abstract}

This study evaluates the impact of intermetallic compound (IMC) thickness on thermomechanical reliability of lead-free $\mathrm{SnAgCu}$ solder joints in crystalline silicon solar cell assembly with regards to fatigue life. Finite element modelling is used to simulate the non-linear thermomechanical deformation of the joints. Five geometric models of solar cell assemblies with different IMC thickness layers in the range of 1 to $4 \mu \mathrm{m}$ are utilized. The models were subjected to accelerated thermal cycling from $-40{ }^{\circ} \mathrm{C}$ to $85^{\circ} \mathrm{C}$ employing IEC 61215 standard for photovoltaic panels. Creep response of each of the assembly's solder joints to the induced thermal load were simulated using Garofalo-Arrhenius creep model. Simulation results indicate that when IMC thickness grows incrementally to $1,2,2.5,3$ and $4 \mu \mathrm{m}$, thermo-mechanical fatigue life of solder joints diminishes to $13,800,11,800,10,600,9400$ and 7,800 cycles to failure respectively. Thus, solder joint fatigue life decreases as the IMC thickness increases during service lifetime. Therefore, proper design of solder joint in crystalline silicon solar cell assembly must include consideration of IMC layer thickness to prevent premature failure and to ensure fulfilment of desired functional lifetime of 13,688 cycles to failure (25 years).

Keywords: Finite element modelling; Solar cell assembly; Solder joint; Intermetallic compound thickness; Thermo-mechanical reliability; Weibull analysis.

\section{INTRODUCTION}

Most of the photovoltaic (PV) modules produced globally are predominantly made with wafer-based crystalline silicon solar cells. For instance, in 2013, wafer-based crystalline silicon PV module produced made up about $90.956 \%$ of total global module production (Burger, et al., 2014). However, there are challenges with regards to the reliability of wafer-based crystalline silicon PV modules which account for greater percentage of PV module production worldwide. The PV modules are expected to have 25 years lifetime or 13688 cycles to failure in operation (Guyenot, et al., 2011). Unfortunately, there have been reports of premature failure of these modules. In particular, untimely failure of solder joints has been identified as a key thermomechanical reliability issue in crystalline silicon PV modules (McCluskey, 2010; 
Cuddalorepatta, et al., 2010). Therefore, there is an urgent need to improve the reliability of wafer-based crystalline silicon PV modules right from the manufacturing process.

The process of manufacturing wafer-based crystalline silicon PV modules begins with printing of silver (Ag) busbar electrode unto the front surface of solar cell (Zarmai, 2016). The next step is high temperature soldering of copper ribbon strip on the printed Ag busbar while an extended part of the ribbon strip is soldered to the back of a neighbouring cell. This forms a series connection of one solar cell connected to a neighbouring cell. At the present time, leadfree solder alloys such as tin-silver-copper (SAC) alloys are used for the interconnection of solar cells as a replacement of the hazardous lead-based solder alloys which were formerly used. The interconnection of these solar cells at high temperature results in the diffusion and metallurgical reaction between copper $(\mathrm{Cu})$ and tin $(\mathrm{Sn})$ elements as well as silver $(\mathrm{Ag})$ and $\mathrm{Sn}$ elements to form intermetallic compound (IMC) layers at the interfaces. The layer of IMC formed at the interface joint between solder and copper ribbon consists mainly of $\mathrm{Cu}_{3} \mathrm{Sn}$ and $\mathrm{Cu}_{6} \mathrm{Sn}_{5} \mathrm{IMCs}_{3}$ while at the $\mathrm{Ag}$ busbar and solder interface joint, the IMC layer consist of $\mathrm{Ag}_{3} \mathrm{Sn}$ intermetallic compound (Schmitt, et al., 2012).

In the course of field operations, PV modules undergo thermo-mechanical fatigue loading due to thermal cycling and differences in the coefficient of thermal expansion (CTE) of the interconnect materials. The resultant thermal effect of the thermo-mechanical fatigue loading is further growth of the IMCs in the solder joint. In an experimental study, Schmitt et al. (2012) reported that IMCs decrease the performance and reliability of solder joints in PV modules.

The effect of formation and growth of IMC on reliability of solder joints in crystalline silicon solar cells have been reported in previous studies which include references (Schmitt, et al., 2012), (Jung and Kontges, 2013) and (Yang, et al., 2014). These investigations used experimental methods and also studied the effect of IMC on the mechanical strength of solder joints as well as adhesion and durability of the joints. Literature on research employing finite element modelling (FEM) to study reliability of interconnection in PV modules which incorporates IMC is scarce - notwithstanding that FEM method is a valuable tool for product design and development (Chiou, 2011). The FEM method is used in this study to simulate the non-linear creep deformation of solder joints in crystalline silicon solar cell assembly.

The layer of IMC grows continuously throughout the lifetime of solder joint. However, in order to model and simulate its growth, specific values in incremental order are used. This study utilizes five geometric models of solar cell assemblies with the following different IMC layer thicknesses: 1, 2, 2.5, 3 and $4 \mu \mathrm{m}$. The models were subjected to accelerated thermal cycling from $-40{ }^{\circ} \mathrm{C}$ to $85{ }^{\circ} \mathrm{C}$ utilising IEC 61215 standard for photovoltaic panels (Amdt and Puto, 2011). The study evaluates the quantitative damage of the solder joints using the concept of hysteresis loop. In addition, the study evaluates the thermally induced creep deformation stored in solder joint as strain energy and its effects in the whole joint with IMC layer as well as in the solder region. The values of creep strain energy density were determined and used to predict the service lifetimes of the models. The solar cell solder joint service life for the five geometric models can be predicted using fatigue models such as Syed's model (Syed, 2014). The values of average change in accumulated creep strain energy density per cycle $\left(\Delta \omega_{\text {acc }}\right)$ of the models were used to compute fatigue life of each model. The fatigue life is also stated as mean-time-to-failure (MTTF) or cycles to failure. Hence, presented in subsequent sections are the materials and 
methods adopted for this study followed by modelling and simulation results obtained and discussion. The presentation of results and discussion is made up of the following five subsections: study on equivalent stress, study on equivalent creep strain, evaluation of hysteresis loop of solder joints in solar cell assembly, evaluation of accumulation of strain energy density and effect of IMC on solder joint fatigue life.

\section{MATERIALS AND METHODS}

\subsection{Materials and their Properties}

Crystalline silicon solar cell assembly consists of various materials with dissimilar properties. Presented in Fig. 1 is schematic of cross section of such a typical crystalline silicon solar cell assembly showing the various component materials.

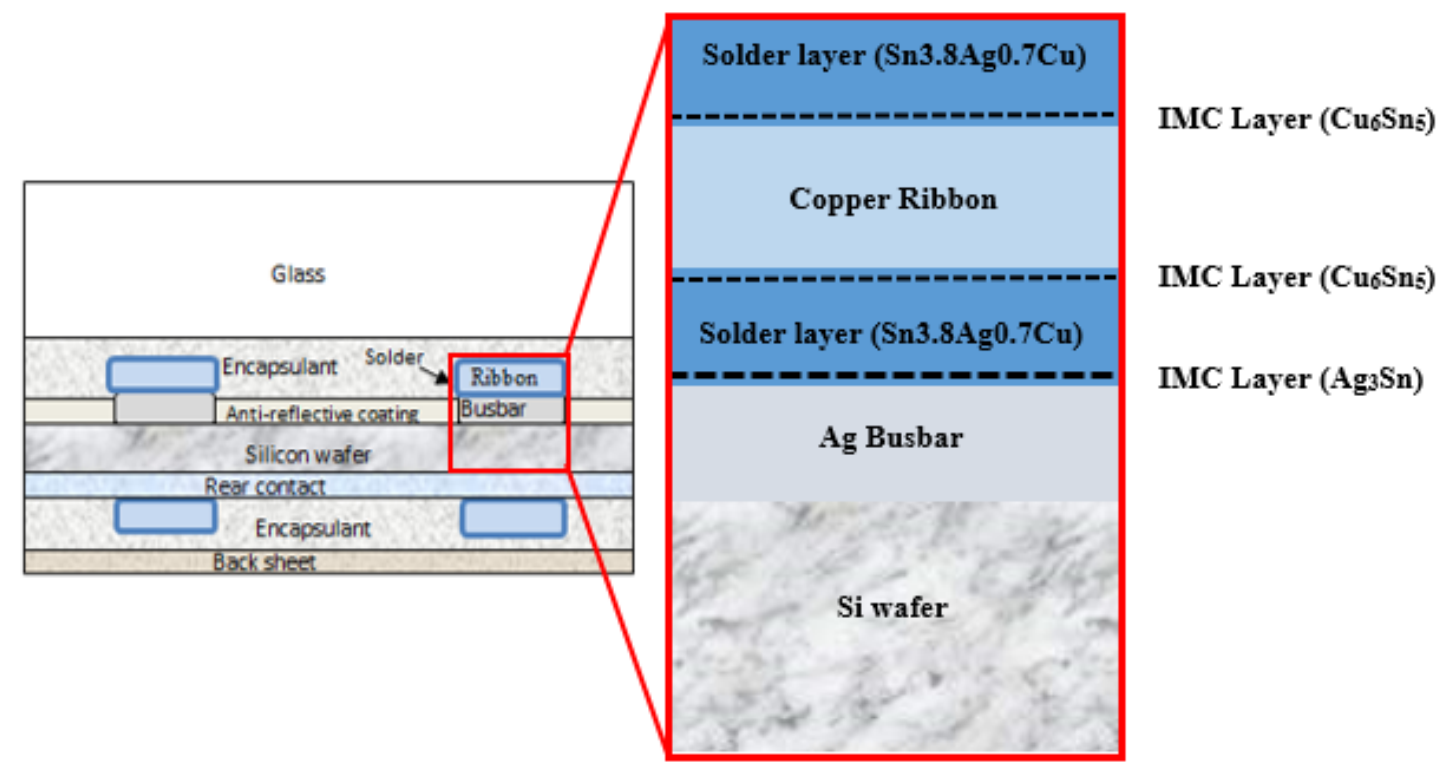

Figure 1. Schematic of cross-section of typical crystalline Si solar cell assembly showing:

(a) Encapsulated solar cell assembly

(b) Soldered interconnects including IMC layers

In carrying out the modelling of the solar cell assembly, ANSYS DesignModeler is used to build the geometric model of $156 \times 156 \mathrm{~mm}^{2}$ multi crystalline silicon solar cell assembly and to assign the component materials. The materials used in the geometric model include Sn-3.8Ag$0.7 \mathrm{Cu}, \mathrm{Cu}$ ribbon, $\mathrm{Ag}$ busbar, IMCs, Si wafer, Al rear contact and Tedlar backsheet and their properties such as Young's modulus, CTE, Poisson ratio and shear modulus are also taken into consideration. The growth of IMC layer gradually reduces solder volume at the joint interface and it represents such in the models. Presented in Table 1 are mechanical properties of materials in solar cell assembly used in this study. 
Table 1: Mechanical properties of materials in solar cell assembly (Zarmai, et al, 2016)

\begin{tabular}{lllll}
\hline Component & $\begin{array}{l}\text { Young's modulus } \\
\mathrm{E}(\mathrm{GPa})\end{array}$ & $\begin{array}{l}\mathrm{CTE} \\
\alpha\left(10^{-6} /{ }^{\circ} \mathrm{C}\right)\end{array}$ & $\begin{array}{l}\text { Poisson ratio } \\
v\end{array}$ & $\begin{array}{l}\text { Shear modulus } \\
\mathrm{G}(\mathrm{GPa})\end{array}$ \\
\hline Glass & 73.3 & 8.5 & 0.21 & 30 \\
\hline Eva encapsulant & 0.011 & 270 & 0.4999 & 0.004 \\
\hline Cu ribbon & 129 & 17 & 0.34 & 48 \\
\hline IMC & 110 & 23 & 0.3 & 42 \\
\hline $\begin{array}{l}\text { Solder } \\
\text { (Sn3.8Ag0.7Cu })\end{array}$ & 43 & 23.2 & 0.3 & 17 \\
\hline Ag busbar & 72.4 & 10.4 & 0.37 & 26 \\
\hline Si wafer & 130 & 3.5 & 0.22 & 53 \\
\hline Al rear contact & 69 & 11.9 & 0.33 & 26 \\
\hline Tedlar backsheet & 1.4 & 30 & 0.4 & 0.5 \\
\hline
\end{tabular}

\subsubsection{Constitutive Solder Model}

Elastic and inelastic deformation occur in solder joints in solar cell assemblies as a result of thermo-mechanical loading during accelerated thermal cycling tests as well as in field service. The elastic and inelastic deformation behaviour of the solder alloy is described by constitutive models. One of the solder constitutive models commonly used in finite element analysis (FEA) is the Garofalo-Arrhenius creep model. Creep of a solder material is often characterized by its steady-state creep strain rate (Pang, 2012). This study utilized the hyperbolic sine creep equation to simulate the creep behaviour of $\mathrm{Sn}-3.8 \mathrm{Ag}-0.7 \mathrm{Cu}$ solder joints. This equation in the format containing Garofalo-Arrhenius creep model constants is given by (Syed, 2004):

$\dot{\varepsilon}_{c r}=C_{1}\left[\sinh \left(C_{2} \sigma\right)\right]^{C_{3}} \exp ^{-C_{4} / T}$

The constants $\mathrm{C}_{1}, \mathrm{C}_{2}, \mathrm{C}_{3}$ and $\mathrm{C}_{4}$ are creep parameters. Their values for $\mathrm{Sn}-3.8 \mathrm{Ag}-0.7 \mathrm{Cu}$ solder are presented in Table 2.

Table 2: Generalized Garofalo Creep Parameters for Sn3.8Ag0.7Cu solder (Syed, 2004)

\begin{tabular}{lllll}
\hline Constant & $\mathrm{C}_{1}$ & $\mathrm{C}_{2}$ & $\mathrm{C}_{3}$ & $\mathrm{C}_{4}$ \\
\hline Units & $1 / \mathrm{sec}$ & $1 / \mathrm{Pa}$ & - & $\mathrm{K}$ \\
Value & $2.78 \mathrm{E}+05$ & $2.45 \mathrm{E}-08$ & 6.41 & 6500 \\
\hline
\end{tabular}




\subsubsection{Fatigue Life Prediction Model}

The standard method used to evaluate the fatigue life of solder is based on the inelastic response of solder when subjected to thermo-mechanical loading. The primary damage mechanism for $\mathrm{SnAgCu}$ solder during thermal cycling is creep and it is used to simulate the material behaviour. Therefore, the life prediction model has to be theoretically based on creep deformation (Syed, 2004).

The accumulated creep strain energy density per cycle is used to predict fatigue life of solder joints subjected to thermal cycling loading. Number of cycles to failure is given by:

$$
N_{f}=\left(W^{\prime} W_{a c c}\right)^{-1}
$$

where, $N_{f}$ is number of repetitions or cycles to failure, $W^{\prime}$ is creep energy density for failure and $W_{a c c}$ is accumulated creep energy density per cycle. The constant $W^{\prime}$ has been determined experimentally as 0.0019 (Syed, 2004).

\subsection{Loads and Boundary Conditions}

The geometric models used in this study were subjected to six accelerated thermal cycling in 25 load steps between $-40{ }^{\circ} \mathrm{C}$ to $85{ }^{\circ} \mathrm{C}$ utilising IEC 61215 standard for photovoltaic panels (Zarmai, 2016). The temperature loading started from $25^{\circ} \mathrm{C}$, ramped up at a rate of $3{ }^{\circ} \mathrm{C} / \mathrm{min}$ to $85{ }^{\circ} \mathrm{C}$, where it had hot dwell for $20 \mathrm{~min}$. It was then ramped down to $-40{ }^{\circ} \mathrm{C}$ at a rate of 6 ${ }^{\circ} \mathrm{C} / \mathrm{min}$, where it had cold dwell for $20 \mathrm{~min}$. Presented in Fig. 2 is the thermal cycling profile used to simulate actual cycling profile used during thermal load test.

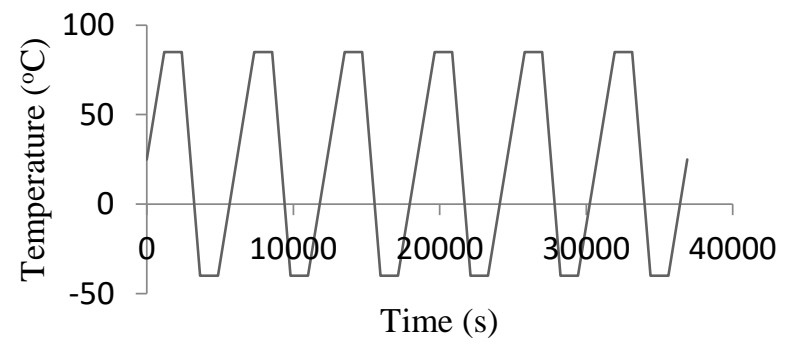

Figure 2. Plot of temperature profile of thermal load test condition used in the solar cell assembly

\subsection{Finite Element Modelling}

The methodology adopted in this study involves the utilization of FEM to investigate the effect of IMC layers on the thermo-mechanical reliability of solder joints in multi-crystalline silicon solar cell assembly. Likewise, Garofalo-Arrhenius creep model was used for this study. The study of induced strain in $156 \times 156 \mathrm{~mm}^{2}$ multi crystalline silicon solar cell assembly was carried out using ANSYS Academic Research Finite Element package. While, ANSYS DesignModeler is used to build the geometric models and ANSYS Static Structural code is used for analysis. The geometric model of solar cell assembly has two printed Ag bus bars on its front surface and on the bus-bars, copper ribbon strips are soldered. Due to the magnitude of 
computations involved, the High Performance Computation (HPC) was executed using a Bespoke Work Station computer in the School of Engineering in simulating the assemblies. Quarter symmetry of the geometric model was simulated to lessen modelling time and disc space. The static structural response of the geometric models subjected to accelerated thermal cycling utilising IEC 61215 standards for photovoltaic panels were simulated.

Presented in Fig. 3 is a cross-section of solar cell model showing IMC thickness.

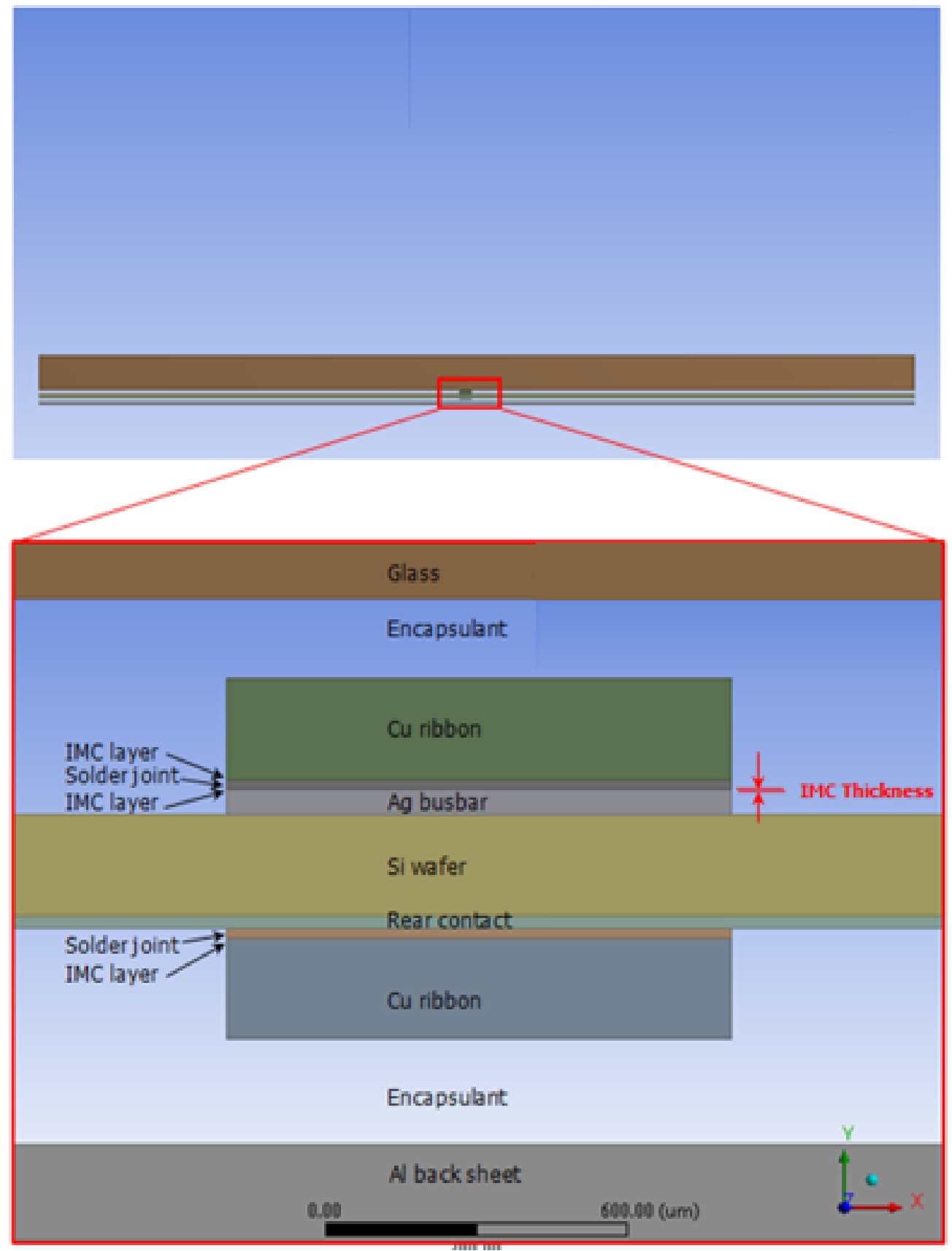

Figure 3. Cross-section of solar cell model showing IMC Thickness 
The geometric models used in this study have IMC layers at the two solder joint interfaces. The thickness of the IMC layers at the two sides of solder layer is assumed to be the same. Furthermore, this study utilized five finite element geometric models of solar cell assembly with IMC layer thickness of $1 \mu \mathrm{m}, 2 \mu \mathrm{m}, 2.5 \mu \mathrm{m}, 3 \mu \mathrm{m}$ and $4 \mu \mathrm{m}$ as presented in Table 2. These IMC layer thicknesses used in the models are within the range of thicknesses obtained experimentally by Schmitt et al. (2012) and Yang et al. (2014). The models were assigned numbers 1, 2, 3, 4 and 5 respectively and simulated separately. All the five models have the same solder joint thickness of $20 \mu \mathrm{m}$ as well as same solder joint width of $1000 \mu \mathrm{m}$. Thus the total volume in the whole solder joint for all the models is the same $1.56 \mathrm{~mm}^{3}$. In all the geometric models, the whole solder joint comprises three regions: IMC layer at the interface joint between solder and $\mathrm{Cu}$ ribbon; solder region; and IMC at the interface joint between solder and Ag bus-bar. The parameters of all the five models are presented in Table 3. Note that the actual solder thickness (stand-off height minus the two IMC layer thicknesses) are also shown in Table 3. An observation of the table shows that each model has a different IMC thickness from the other such that as the IMC thickness increases, volume in solder region decreases.

Table 3: Parameters of solder joints containing varied IMC thickness

\begin{tabular}{ccccccc}
\hline $\begin{array}{c}\text { Model } \\
\text { number }\end{array}$ & $\begin{array}{c}\text { IMC } \\
\text { thickness } \\
(\mu \mathrm{m})\end{array}$ & $\begin{array}{c}\text { Solder joint } \\
\text { thickness } \\
(\mu \mathrm{m})\end{array}$ & $\begin{array}{c}\text { Actual solder } \\
\text { thickness } \\
(\mu \mathrm{m})\end{array}$ & $\begin{array}{c}\text { Solder joint } \\
\text { width }(\mu \mathrm{m})\end{array}$ & $\begin{array}{c}\text { Whole joint } \\
\text { Vol. }\left(\mathbf{m m}^{3}\right)\end{array}$ & $\begin{array}{c}\text { Solder region } \\
\text { Vol. }\left(\mathbf{m m}^{3}\right)\end{array}$ \\
\hline 1 & 1.0 & 20 & 18 & 1000 & 1.56 & 1.404 \\
2 & 2.0 & 20 & 16 & 1000 & 1.56 & 1.248 \\
3 & 2.5 & 20 & 15 & 1000 & 1.56 & 1.170 \\
4 & 3.0 & 20 & 14 & 1000 & 1.56 & 1.092 \\
5 & 4.0 & 20 & 12 & 1000 & 1.56 & 0.936 \\
\hline
\end{tabular}

The data in Table 3 is used to plot solder region volume against IMC thickness and is presented in Fig. 4. It can be observed in Fig. 4 that as thickness of IMC layer increases from the low value in Model 1 to the high value in Model 5, the solder region volume decreases accordingly. Thus, for the thin IMC thickness in Model 1, solder volume is large whereas for the thick IMC thickness in Model 5, solder volume is small. 


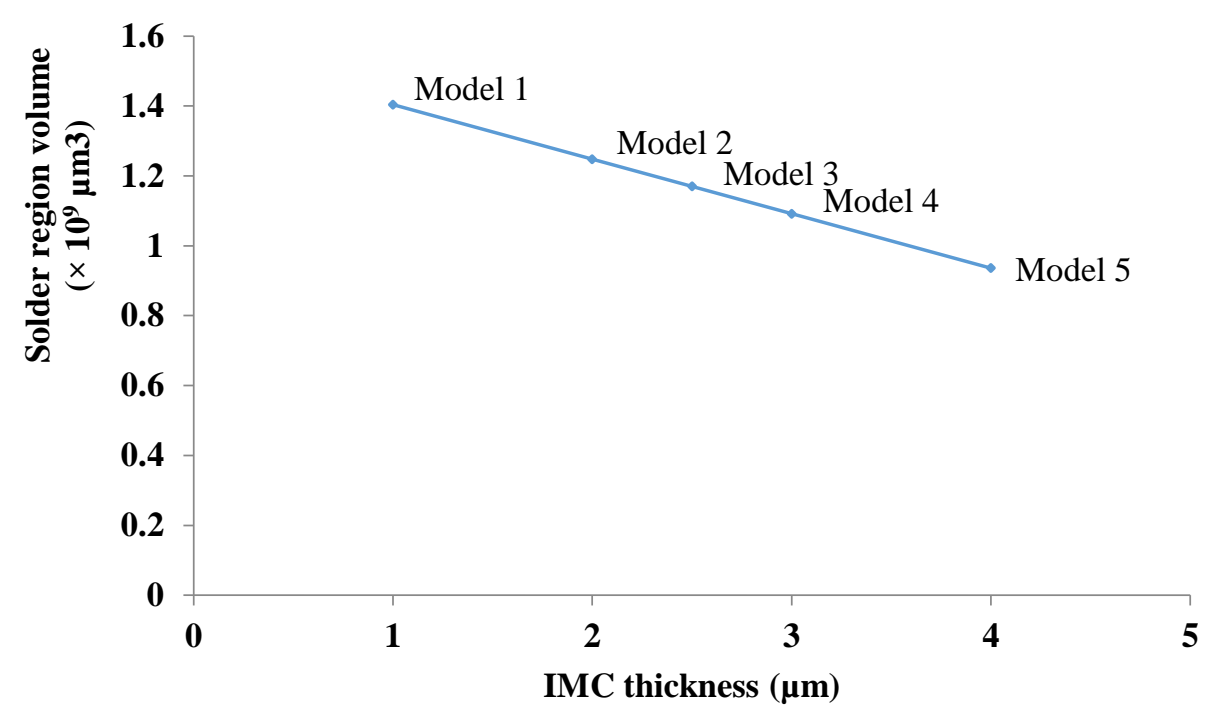

Figure 4. Plot of solder region volume against IMC thickness

In the analysis of simulation results, model based on solder region is termed model $i$ solder region. The "i" designates models 1-5 used in this study. The creep strain, stress and strain energy of solder region models are evaluated and comparatively analysed. Furthermore, accumulated creep strain energy density in the solder joints of each model was determined and compared. Moreover, the average accumulated creep strain energy density in the solder joint was used for life prediction computation of the joint in each model.

\section{RESULTS AND DISCUSSION}

\subsection{Study on equivalent stress}

The induced stress in solar cell solder joint studied for all five models is presented. The stress is analysed for both the whole solder joint inclusive of IMC layers at the two interfaces as well as solder only region exclusive of IMC layers. Simulation results were obtained for all five models. A typical result is presented in Fig. 5 for Model 1 showing damage distribution of equivalent stress on the whole solder joint. Figure 5 reveal that Model 1 has maximum stress at the end of the right hand side of the longitudinal section of the solder joint. Furthermore, it can be observed that the values of induced stress in the solder joint of Model 1 is 6.62MPa. Besides, the damage distribution seems to be uniformly spread along the entire longitudinal section of the solder joint the models. In the case of the other four models, some similarities as well as variations of damage distribution were observed. 


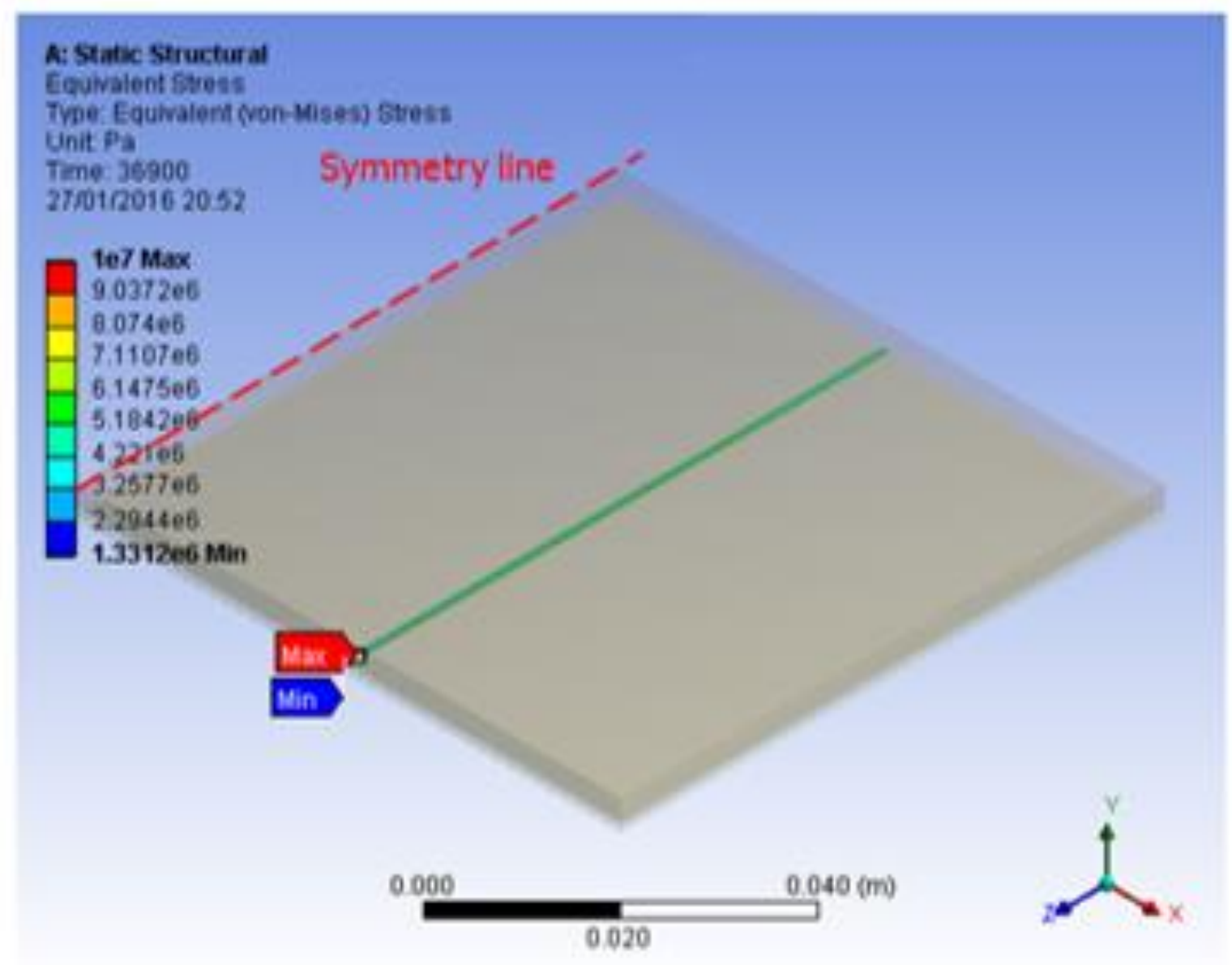

Figure 5. Damage distribution of equivalent stress on the whole solder joint in a model showing stress on whole joint

Furthermore, while the damage in the whole solder joint appears to be mild as shown in the preceding model of Fig. 5, the actual situation in the solder only region is different. Figure 6 shows the damage in the solder only region in Model 1 subjected to stress. In all the five models, the damage in the solder only region is more pronounced than in the whole solder joint. Consequently, models with whole solder joint which include IMC may give a false impression of the damage in the solder joint. Therefore, it is crucial to separately study the solder only region which provides the critical interconnection for solar cell assembly. The maximum stress in the solder joint of Model 1 presented in Fig. 6 is located at the end of the right hand side of the solder joint and the damage spreads along the longitudinal section of the joints. In the other four models, the maximum stress is located at either similar or dissimilar locations.

Additionally, a close observation of the IMC layers in the model shows that the IMC layer at the Ag bus-bar/solder interface has greater damage distribution compared to the IMC layer at the $\mathrm{Cu}$ ribbon/solder interface. This is consistent with experimental findings by Schmitt et al. (2012). 
Therefore, the differences observed in the two sets of models for whole solder joint and solder only regions further justifies the need to study the effect of IMC inclusion in solder joint models for accurate prediction of solder joint fatigue life.

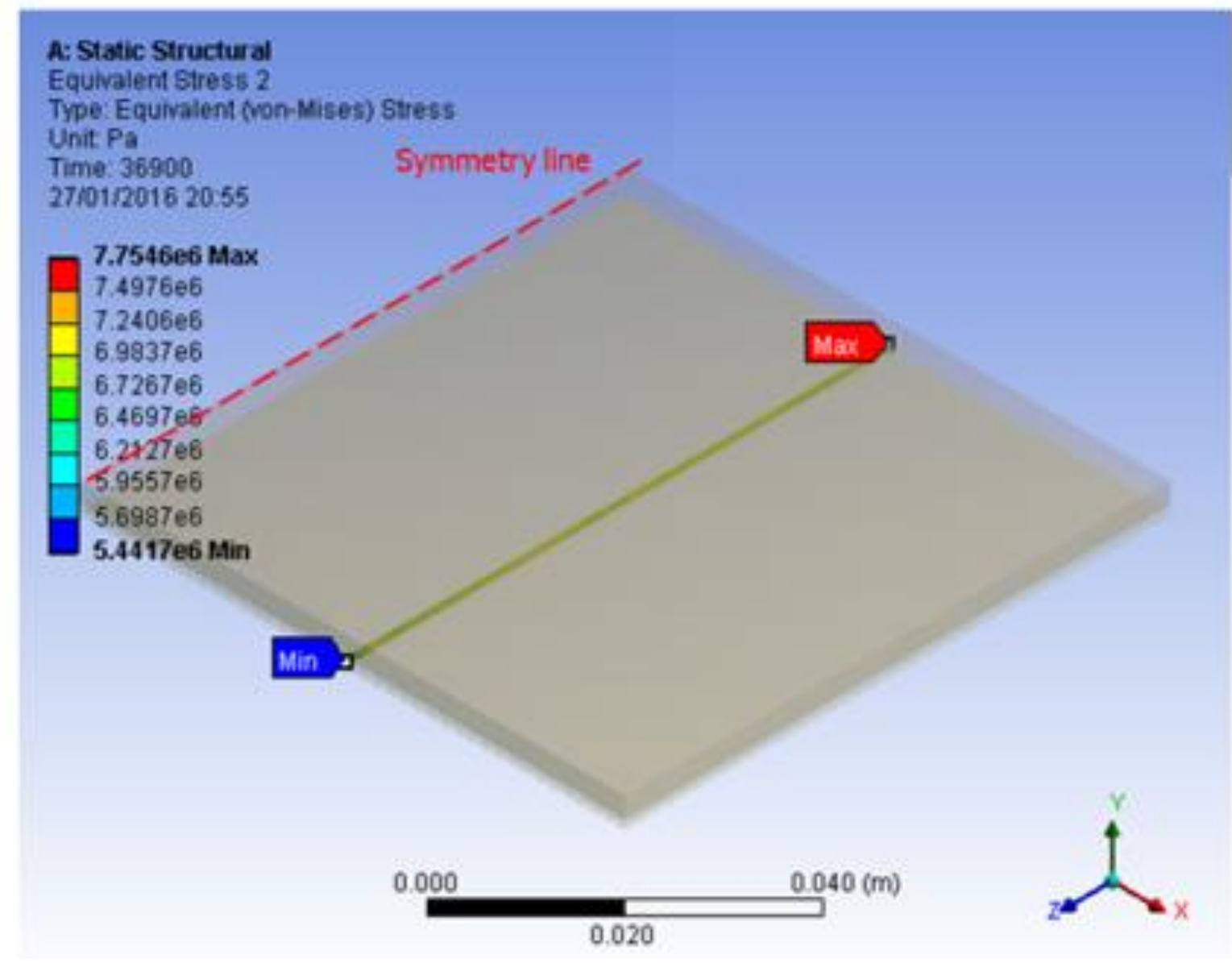

Figure 6. Damage distribution of equivalent stress on the solder only region showing stress on a model for solder only region

\subsection{Study on equivalent creep strain}

Presented in Fig. 7 is a typical simulation result obtained for Model 1 showing damage distribution of equivalent creep strain on solder joint of solar cell assembly. The figure shows the maximum creep strain in solder joint of Model 1 located a few millimetres to the right hand side of the joint and the damage spread along the longitudinal section. The other four models have maximum creep strain in solder joint at comparable or varied locations. 


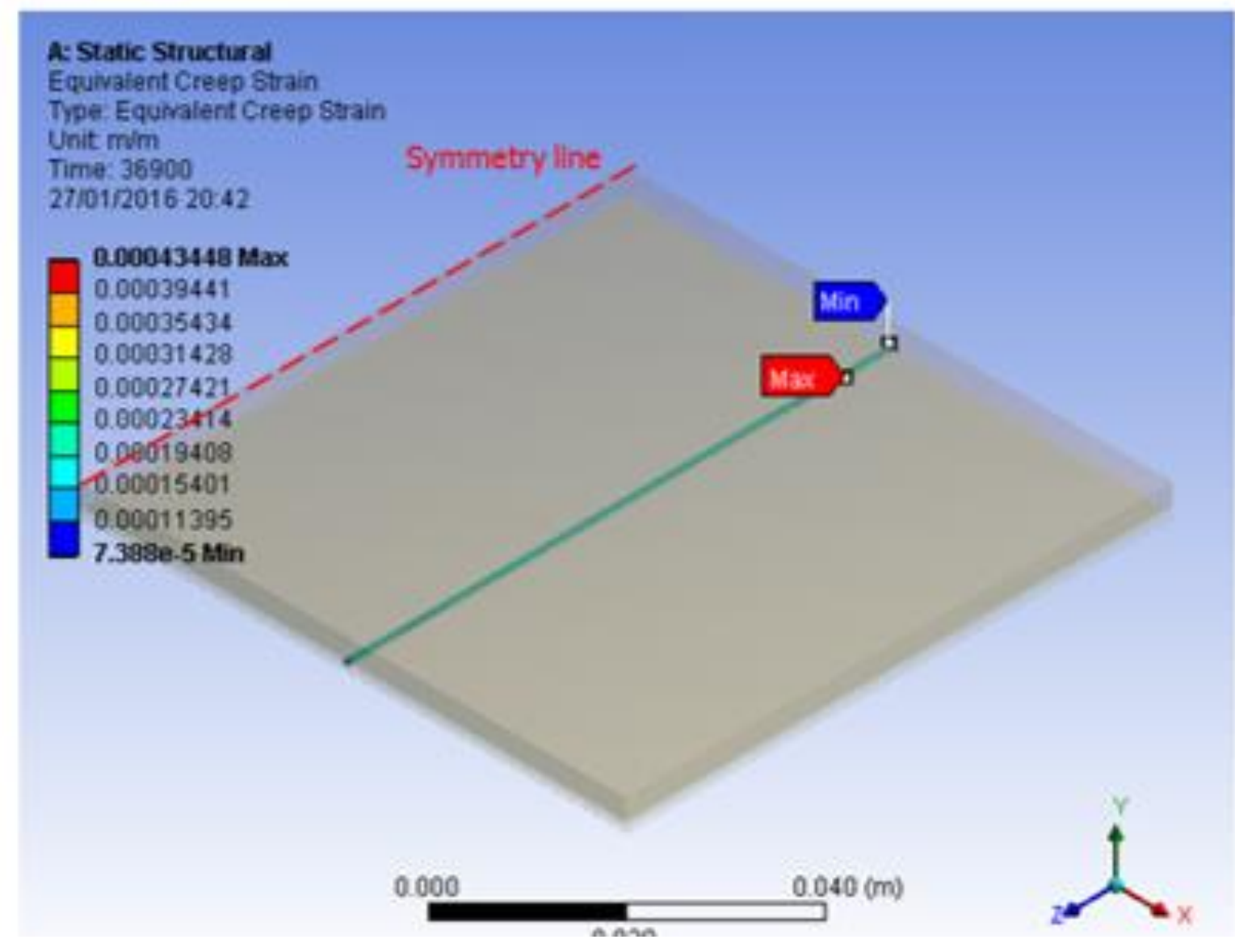

Figure 7. Damage distribution of equivalent creep strain on the whole solder joint showing strain on a model for whole joint

The study of damage distribution of equivalent creep strain on whole solder joints of all the five models show that the largest maximum equivalent creep strain is $9.7517 \mathrm{E}-04 \mathrm{~m} / \mathrm{m}$ in Model 5. This concurs with the largest IMC thickness of $4 \mu \mathrm{m}$ of Model 5 and which also has the smallest solder region volume of $0.936 \mathrm{~mm}^{3}$ as can be seen in Table 2. Conversely, Model 1 has the least maximum equivalent creep strain of $4.3448 \mathrm{E}-04 \mathrm{~m} / \mathrm{m}$. This is in accordance with the smallest IMC thickness of Model 1 and the largest solder region volume of $1.404 \mathrm{~mm}^{3}$. Based on these results, it can be concluded that larger IMC thickness in solder joint induces the joint to experience larger strain. On the other hand, smaller IMC thickness in solder joint indulges the joint to experience lesser strain. Therefore, the growth of IMC thickness considerably impacts solder joint in solar cell assembly.

\subsection{Evaluation of hysteresis loop of solder joints in solar cell assembly}

Presented in Figs. 5, 6 and 7 are damage distribution of stress and creep strain on solder joint of five models. As earlier stated, Fig. 5 shows the stress in the whole joint of the models whereas 
the stress in solder only region is presented in Fig. 6. However, the stress values in the whole joint are different from the stress values in the solder only region. In order to highlight the differences in stress values between whole joint and solder only region, a plot of the relationship between stress and creep strains in the solder joints is made using values obtained from simulation results. Figure 8 shows the plot of the relationship between stress and creep strains in the solder joints of solar cell models for both the whole joint and solder only region. The figure shows hysteresis loops each for models of whole joint and solder region which formed as a result of thermal cycling. The area of each hysteresis loop represents the visco-plastic energy density per cycle or simply the fatigue damage accumulating per cycle in the models. It can be observed in the figure that each model has a different hysteresis loop; therefore, the fatigue damage in each model is different from the other. Furthermore, the induced stress in models of whole joint is higher than in models with solder region only due to the presence of IMCs in the whole joint.

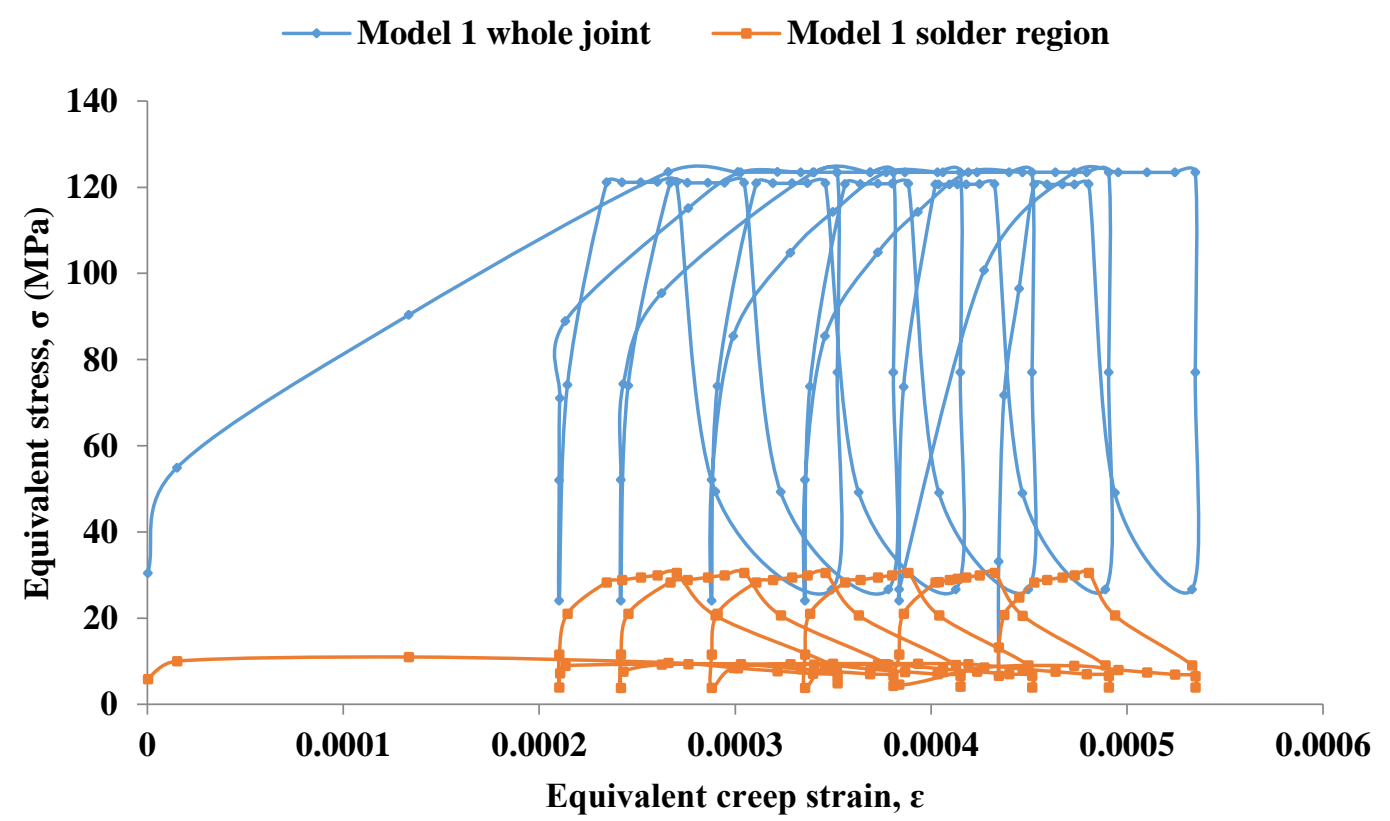

Figure 8. Relationship between stress and creep strain in a solar cell model of the whole joint and solder region

In addition, it can be observed from Fig. 8 as well as from Figs. 5 and 6 that values of equivalent stress for models of whole joints are higher than those of solder only region. For instance, the largest maximum equivalent stress is about $10 \mathrm{MPa}$ as can be observed in Fig. 5 models of whole joints. On the other hand, the largest maximum equivalent stress is about 7.7546MPa as shown in Fig. 6 for those of solder only region. Thus induced stress in whole solder joint is higher than that of solder only region. This suggests that the presence of IMC in 
whole solder joint results in larger induced stress in the solder joint compared with solder only region.

\subsection{Evaluation of accumulation of strain energy density}

During thermal cycling, induced creep deformation occurs and is stored internally throughout the volume of the solar cell solder joint as creep strain energy. The volume average method is used to convert the creep strain energy obtained from simulation results into accumulated strain energy density for each of the five models. In order to get accurate results, average accumulated strain energy density values are used for computations. Presented in Fig. 9 is a plot of accumulated strain energy density in $\mathrm{mJ} / \mathrm{mm}^{3}$ against temperature profile step. It can be observed in Fig. 9 that for solder only region Models 1 and 5 have the least and highest average values of accumulated strain energy density in the solder only regions as $0.03818 \mathrm{~mJ} / \mathrm{mm}^{3}$ and $0.06735 \mathrm{~mJ} / \mathrm{mm}^{3}$ respectively. The average values of accumulated strain energy density in the solder only regions are presented in Table 4 . The results implies that as IMC thickness increases, accumulated strain energy density increases as well in the solder regions. This further confirms that solder joints are affected by the presence of IMCs.

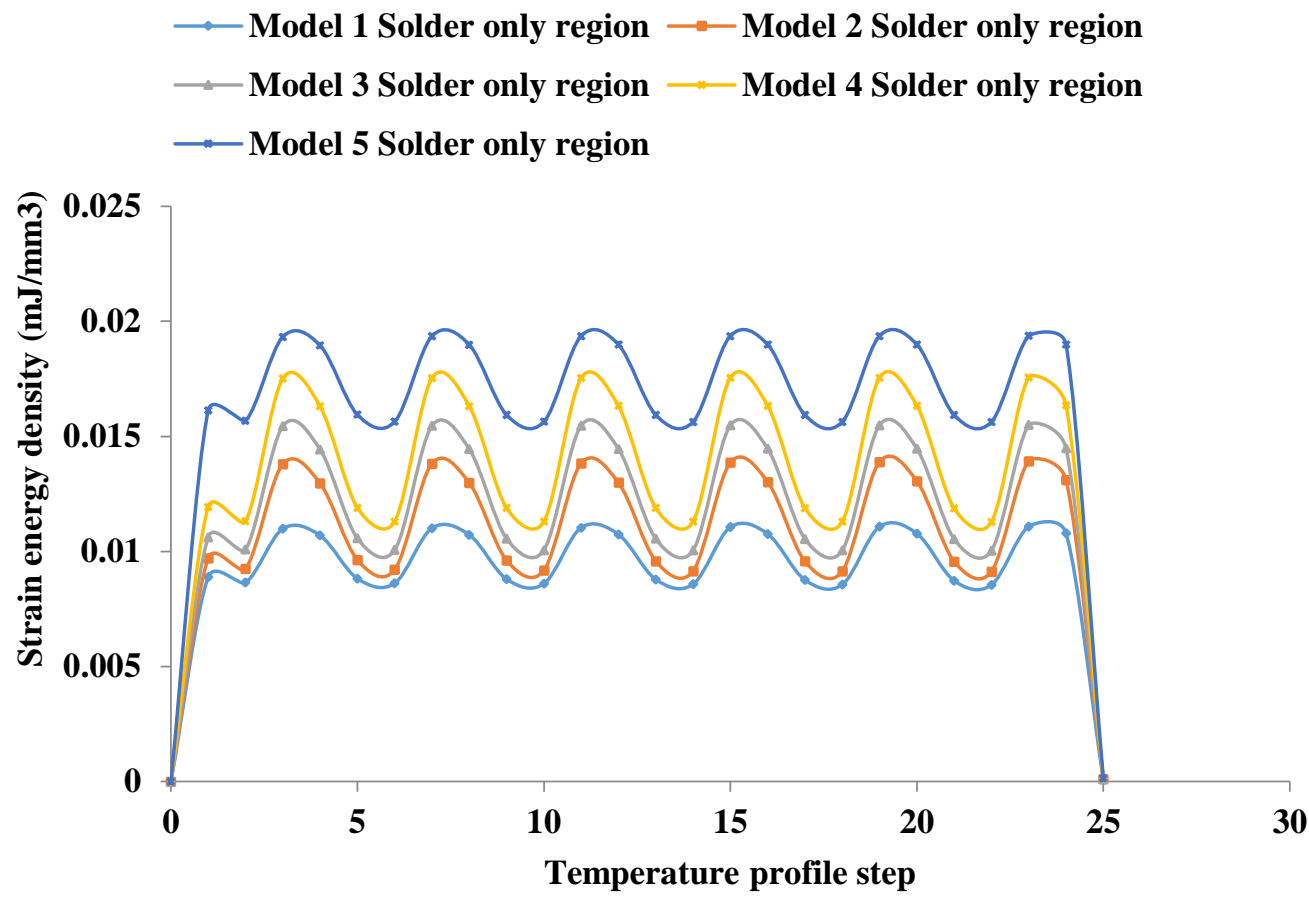

Figure 9. Plot of strain energy density for models against temperature profile step showing strain energy density for solder only region 


\subsection{Effect of IMC layer on solder joint fatigue life}

The solar cell solder joint service life for the five geometric models were predicted using Syed's fatigue model. The values of average change in accumulated creep strain energy density per cycle $\left(\Delta \omega_{\text {acc }}\right)$ of the models were inputted into Eq. 2 to compute fatigue life of each model. The results of the fatigue life computation for the five models are presented in Table 4 consisting of as predicted life for solder only regions. The results in Table 4 indicate that Model 1 with IMC thickness of $1 \mu \mathrm{m}$ for solder region has the highest fatigue life of 13800 cycles to failure. Likewise, Model 5 with IMC thickness of $4 \mu \mathrm{m}$ for solder region has the lowest fatigue life of 7800 cycles to failure. Moreover, these results are used to analyse the effect of IMC layer on solder fatigue life prediction.

Table 4: Predicted fatigue life for models with varied IMC layer thickness

\begin{tabular}{cccc}
\hline $\begin{array}{c}\text { Model } \\
\text { No }\end{array}$ & $\begin{array}{c}\text { IMC } \\
\text { thickness }(\mu \mathrm{m})\end{array}$ & $\begin{array}{c}\text { Solder region } \\
\Delta \omega_{\text {acc }} \\
\left(\mathrm{mJ} / \mathrm{mm}^{3}\right)\end{array}$ & $\begin{array}{c}\text { Solder region } \\
\text { Predicted life } \\
(\text { cycles })\end{array}$ \\
\hline 1 & 1.0 & 0.03818 & 13800 \\
2 & 2.0 & 0.04458 & 11800 \\
3 & 2.5 & 0.04950 & 10600 \\
4 & 3.0 & 0.05609 & 9400 \\
5 & 4.0 & 0.06735 & 7800 \\
\hline
\end{tabular}

Results of fatigue life in Table 4 are plotted in Fig. 10 showing whole joint life and solder region life versus IMC thickness. It can be observed from Fig. 10 that as IMC thickness increases, fatigue life for solder region decreases. 


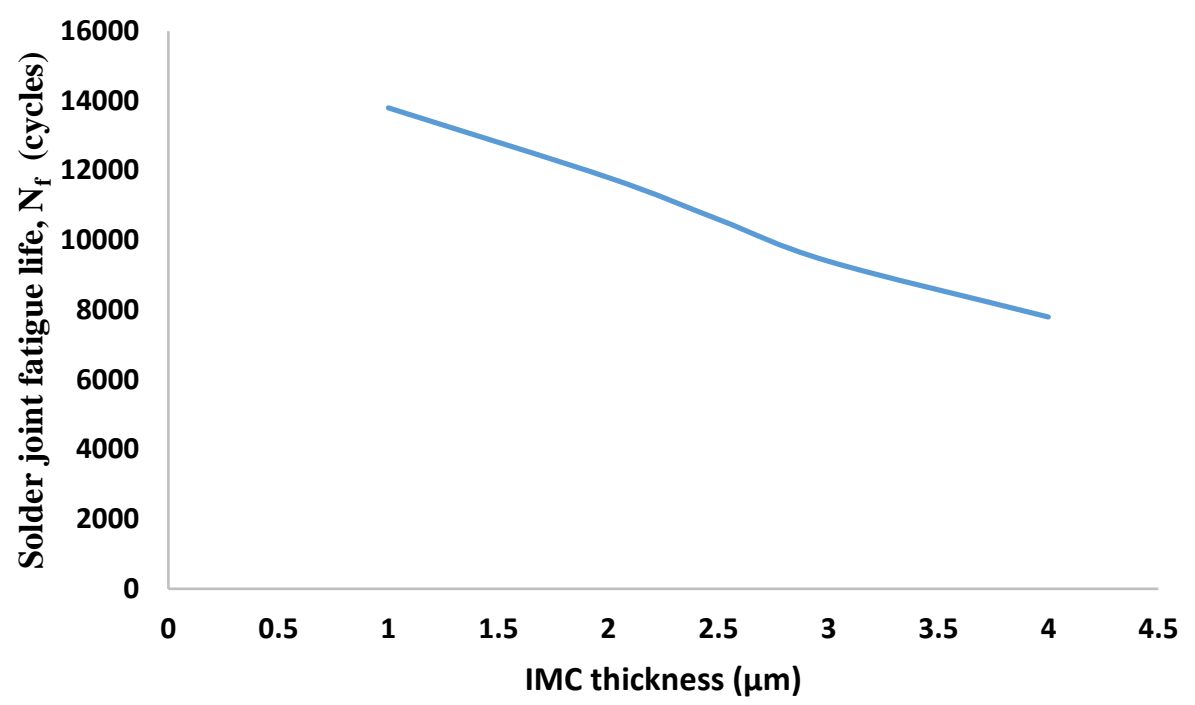

Figure 10. Plot of predicted solder joint fatigue life versus IMC thickness

It has been reported by several researchers that numerous PV modules fail during field operations or accelerated life testing. According to an IEA report on field study of PV modules in operation for 8 years, Kontges et al. (2014) reported that $2 \%$ of the modules were expected to fail after 11-12 years due to defective interconnections. Similarly, DeGraaff et al. (2011) reported that a field observation of PV modules produced by 21 different manufacturers revealed that about $4 \%$ of the modules showed signs of failure during the first 15 years. Furthermore, Kohl et al. (2009) in SunPower (2013) reported that in a German four-year project, a group of PV modules from 7 different manufacturers were subjected to damp heat ageing test. The results showed significant performance degradation such that projected lifetime was less than 20 years (10950 cycles to failure). Likewise, in an experimental study, Kumar and Sarkar (2013) subjected 20 PV modules to a single constant stress accelerated life test and computed the least life to be 21 years (11497 cycles to failure). This accelerated life test result together with ageing test result is used alongside whole solder joint predicted fatigue life for the five models as well as the expected 25 years lifetime or 13688 cycles to failure (Guyenot, et al., 2011) to plot Fig. 11. The Fig. 11 is a plot of IMC layer thickness versus predicted solder joint fatigue life of the five models compared with test and expected life. The plot of the figure reveals that fatigue life of Models 1, 2 and 3 are close to the expected fatigue life of solder joint while Models 4 and 5 have shorter fatigue lives. Experimental test life is the shortest and the reason for this could be due to several factors such as solder joint design, solder composition, experimental set-up or other factors. The reason for the longer fatigue life when IMC thickness is smaller is because as IMC thickness increases, solder volume decreases thereby limiting the capacity and integrity of the solder joint to provide the desired interconnection. Consequently, the solder joint becomes greatly damaged and ultimately results in fatigue failure of the joint. Therefore, the MTTF of the 
assembly solder joints depends on the thickness of IMC layer. Hence, thin IMC layer is better for the solder joint than thick IMC layer. For that reason, solder joints in solar cell assembly should be designed in such a way that minimal IMC layers will develop throughout the lifespan of the joints irrespective of the thermo-mechanical loading applied. This will ensure that the solder joint fulfil their functional life before the IMC layers become detrimentally thick.

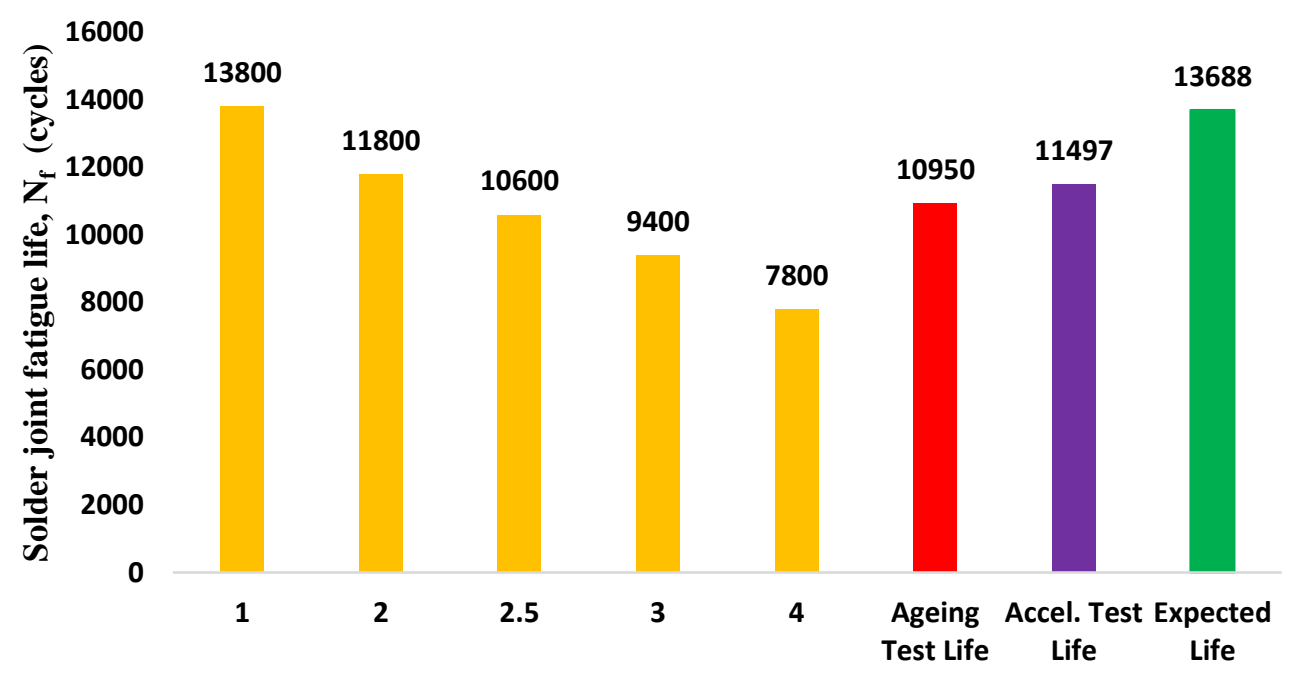

IMC thickness $(\mu \mathrm{m})$

Figure 11. Plot of predicted solder joint fatigue life of models versus IMC layer thickness compared with test and expected values

\section{CONCLUSION}

Presented in this study the impact of IMC thickness on thermo-mechanical reliability of crystalline silicon solar cell solder joint. In the study, the plot of hysteresis loop indicates that the whole joint has larger area than that of solder region. This outcome might be due to more dissipation of accumulated creep strain energy density per cycle in the whole joint which has larger volume when compared with the accumulated creep strain energy density per cycle in the solder region which has smaller volume. Moreover, creep energy is a damage measurement index, therefore it can be resolved that the higher the energy accumulated in a joint without dissipation, the higher the damage on the joint. In addition, the modelling and simulation results show that average accumulated strain energy density values for solder only region in Model 5 is the largest with a value of $0.06735 \mathrm{~mJ} / \mathrm{mm}^{3}$ while Model 1 has the smallest value of $0.03818 \mathrm{~mJ} / \mathrm{mm}^{3}$. This indicates that the solder only region accumulates more damage than the whole joint due to the presence and growth of IMC in the solder joint. Therefore, it can be concluded that the presence and growth of IMC in the joint decreases its thermo-mechanical reliability. This conclusion is further strengthened and confirmed by the result of the study on 
fatigue life of the joints. The finding from analysis of the results demonstrates that the rate of degradation of the joints depends on the thickness of layer of IMC. In this study, it was found that when IMC thickness grows incrementally to $1,2,2.5,3$ and $4 \mu \mathrm{m}$, thermo-mechanical fatigue life of solder joints diminishes to $13,800,11,800,10,600,9400$ and 7,800 cycles to failure respectively. It can be concluded from this result that the fatigue life of solder joints containing IMC layer decreases as the IMC thickness increases during assembly operations as well as during service lifetime of the solar cell assembly. Accordingly, the growth of IMC thickness in solder joint significantly decreases the reliability of the joint in a solar cell assembly of a PV module. Therefore, it is crucial that solder joints in crystalline silicon solar cell assembly should be designed in such a way that minimal IMC layers will develop throughout the service lifespan of the joints irrespective of the thermo-mechanical loading applied. This will ensure that the solder joints are reliable and hence fulfil their desired functional lifetime of at least 13,688 cycles to failure or 25 years before the IMC layers become detrimentally thick.

\section{ACKNOWLEDGEMENTS}

The authors acknowledge funding provided by the Petroleum Technology Development Fund (PTDF), Nigeria, used in carrying out this PG research work.

\section{REFERENCES}

Arndt, R. and Puto, R. (2011) Basic understanding of IEC standard testing for photovoltaic panels. IN Compliance Magazine: 2011 Annual Guide, Hopedale, MA: Same Page Publication, pp. 194-205.

Burger, B., Kiefer, K., Kost, C., Nold, S., Phillips, S., Preu, R., Schindler, R., Schlegl., StrylHipp, G., Willieke, G., Wirth, H., Brucker, I., Haberle, A., Schacht, V. and Warmuth, W. (2014) Photovoltaic Report. Freiburg: Fraunhofer Institute for Solar Energy Systems ISE. pp.1-42.

Chiou, Y-C., Jen, Y-M. and Huang, S-H. (2011) Finite element based fatigue life estimation of the solder joints with effect of intermetallic compound growth. Microelectronics Reliability, 51, pp.2319-2329.

Cuddalorepatta, G., Abhijit, D., Scott, S., Jerome, M., Todd. T. and James L. (2010) Durability of $\mathrm{Pb}$-free solder between copper interconnect and silicon in photovoltaic cells. Progress in Photovoltaics: Research and Applications. 18(3), pp.168-182.

DeGraaff, D., Lacerda, R. and Campeau Z. (2011) Degradation Mechanisms in Si Module Technologies Obsereved in the Field: Their Analysis and Statistics. Photovoltaic Module Reliability Workshop. Golden, Colorado, USA. pp. 1-25.

Guyenot, M., Peter, E., Zerrer, P., Kraemer, F. and Wiese, S. (2011) Enhancing the lifetime prediction methodology for photovoltaic modules. Proceedings of $12^{\text {th }}$ Int. Conf. on Thermal, Mechanical and Multiphysics Simulation and Experiments in Microelectronics and Microsystems. Linz, Austria, pp. 1-4.

Jung, V. and Kontges, M. (2013) Al/Ni: V/Ag metal stacks as rear-side metallization for crystalline silicon solar cells. Progress in photovoltaics, 21(5), pp.876-883. 
Kohl, M., Weiss K., Heck, M. and Philipp, D. (2009) PV Reliability: Results of a German fouryear joint project Part I: Accelerated ageing tests and modelling of degradation. $24^{\text {th }}$ European Photovoltaic Solar Energy Conference and Exhibition. Hamburg, Germany. 21-25 September.

Kontges, M., Kurtz. S., Packard, C., Jahn U., Berger, K.A., Kato, K., Friesen, T., Liu H. and Iseghem H. (2014) Review of Failures of Photovoltaic Modules. International Energy Agency IEA-PVPS Task 13 Report, pp. 1-140.

Kumar, S. and Sarkar, B. (2013) Design for Reliability with Weibull Analysis for Photovoltaic Modules. International Journal of Current Engineering and Technology. 3(1), pp.129-134.

McCluskey, F.P. (2010) Reliability Modeling for Photovoltaic Modules. NREL Photovoltaic Module Reliability Workshop, Denver, Colorado. [Accessed 4 December 2012] Available at: <http://www1.eere.energy.gov/solar/pdfs/pvrw2010_mccluskey.pdf >.

Pang, J.H.L., (2012) Lead Free Solder: Mechanics and Reliability - Theory on Mechanics of Solder Material. Berlin: Springer.

Schmitt, P., Kaiser, P., Savio, C., Tranitz, M. and Eitner, U. (2012) Intermetallic Phase Growth and Reliability of Sn-Ag-Soldered Solar Cells. Energy Procedia. 27, pp.664-669.

Syed, A. (2004) Accumulated Creep Strain and Energy Density Based Fatigue Life Prediction Models for SnAgCu Solder Joints. Proceedings of 54 ${ }^{\text {th }}$ ECTC. Las Vegas, USA. pp.737-746.

SunPower (2013) SunPower Module 40-year Useful Life. SunPower Corporation, USA. pp. 114.

Yang, T.L., Huang K.Y., Yang, S., Hsieh, H.H. and Kao, C.R. (2014) Growth kinetics of $\operatorname{Ag}_{3} \mathrm{Sn}$ in silicon solar cells with a sintered Ag metallization layer. Solar Energy Materials \& Solar Cells, 123, pp.139-143.

Zarmai, M.T. (2016) Modelling of Solder Interconnection's Performance in Photovoltaic Modules for Reliability Prediction [Online]. PhD. Thesis, University of Wolverhampton. [Accessed on 3 April 2019]. Available at: <https://wlv.openrepository.com/handle/2436/617782>.

Zarmai, M.T., Ekere, N. N., Oduoza, C. F., Amalu, E. H. (2016) Optimization of thermomechanical reliability of solder joints crystalline silicon solar cell assembly. Microelectronics Reliability, 59, pp.117-125. 